Middle East Journal of Agriculture Research

EISSN: 2706-7955 ISSN: 2077-4605

DOI: 10.36632/mejar/2020.9.4.80
Volume : 09 | Issue : 04| Oct.-Dec. | 2020

Pages: 1032-1044

\title{
The Influence of plant growth regulators and slicing methods inducing direct organogenesis of meristematic florets of date palm
}

\author{
Eman M.M. Zayed \\ The Central Laboratory of Date Palm Researches and Development, Agriculture Research Center, \\ Cairo, Egypt
}

Received: 12 Oct. 2020 / Accepted 25 Dec. 2020 / Publication date: 30 Dec. 2020

\begin{abstract}
In date palm micropropagation protocols, the female inflorescences play an important role, being available tissue culture-explants, alternatively of the limited number of renewing offshoots explants of date palm that used for in vitro propagation. This study conducted to investigate the effect of different auxins types (2,4-D, NAA, NOA) at different concentrations, supplemented in induction culture medium of constant concentration of cytokinins, on inducing the direct organogenesis by adventitious shoots differentiation, of the date palm immature female inflorescences explants, of Barhe cultivar. Also, the interaction effect of slicing method (for the first time studying) of the starting spikelet explants was studied. The results showed that, the induction medium of the appropriate ratio of the NAA auxin type to cytokinins of induction medium, with applying the slicing method of fine chopping for the cultured spikelet, showed the most satisfying results, of direct adventitious shoots formation, direct somatic embryos, and less formation of direct adventitious roots. Developing the date palm micropropagation protocol by inflorescences explants considered a reliable and rapid opportunity to avoid the shortage of date palm offshoots and covering the commercial demands on the date palm plantlets.
\end{abstract}

Keywords: Date palm micropropagation, female inflorescences, direct organogenesis, chopping, plant growth regulators.

\section{Introduction}

Date palm (Phoenix dactylifera $\mathrm{L}$.) tree, is growing as a monocotyledon plant, belonging to the Arecaceae family. It is a perennial dioecious 'tree' and well known as the most important economic crop in the Middle East and North Africa (Chao and Krueger 2007; Jain, 2012 and Gantait et al., 2018). Date palm plantation widely expanded all over the world, because of the high nutritional value of date fruits, their pharmaceutical importance (ElHadrami, and Al-Khayri, 2012; Al-Mssallem et al., 2019 and El-Dawayati et al., 2020) and also, the important domestic industries products gaining from the tree parts (Gantait et al., 2018). Commonly, this generous tree propagated by the vegetative method through offshoots, but, the slow growth, high costs with a limited number of renewing offshoots are the serious problems faced the vegetative propagation in date palm, which hampering the increasing demands in their plantation expansion (Johnson, 2011 and Abahmane, 2017). Since the sexual propagation of date palm by seeds is not an effective method at all, due to, the highest longevity of the growing period until reaching the bearing stage, moreover, genetic heterozygosity occurrence in the new seedlings progeny (Zayed, 2011). Therefore, the advanced propagation by tissue culture technique, using the meristematic cells of shoot tips (Othmani et al., 2009; Al-Khayri 2011 and Mazri et al., 2018) or immature (Zayed, 2011 and Fayek et al., 2017) and mature (Kriaa et al., 2012 and Zayed, 2017) female inflorescences, has an important role in adjusting the faster and higher production of new plantlets that are true-to-type to the mother plants, which ensuring the expansion of palm plantations. In general, date palm micropropagation can be accomplished through, indirect somatic embryogenesis, where somatic embryos differentiated from the induced embryogenic callus, which subsequently converted into complete plantlets (Fki et al., 2003; Aslam et al., 2011 and El-Dawayati et al., 2018). Meanwhile, the other pathways are, the direct somatic embryogenesis or the direct organogenesis (Bekheet, 2013; Fayek et al., 2017 and Ali and Abdulzhara, 2018), as the complete plantlets are directly produced, without the callus stage interfere. Anywhere, callus phase absence ensures avoidance of the genetic variation among the regenerated plantlets. Furthermore, plants regeneration via direct organogenesis, is the most

Corresponding Author: Eman M.M. Zayed, The Central Laboratory of Date Palm Researches and Development, Agriculture Research Center, Cairo, Egypt 
preferred method for most plants' micropropagation, even if the frequency of plantlets production decreased, but the somaclonal variation occurrence decrease (Asthana et al., 2011; Amit et al., 2014; Kazeroonian et al., 2018 and Zhang et al 2018).

Recently, there is a worldwide increasing demand for in vitro produced plantlets of date palm cultivars. Therefore, there is an urgent need to available source and develop a high-frequency of identical genetic plant regeneration protocols for date palm.

It is worth mention that, various studies in date palm micropropagation have demonstrated female inflorescences explants to be an available and alternative source for shoot tip explants, whenever deficiency of offshoots needed to start the in vitro propagation protocol (Zayed, 2011).

There are several studies on date palm micropropagation by female inflorescences explants using indirect somatic embryogenesis (Abul-Soad 2012 and Zayed and Abdelbar, 2015) but, a limited studies using the direct somatic embryogenesis (Zayed, 2011; Sidky and El-Dawyati, 2012 and Fayek et al.,2017). On the other hand, a few studies conducted to induce the direct adventitious bud (Kriaa et al., 2012; Zayed et al., 2016 and Khierallah et al., 2017). In general, many factors control the meristematic cells morphogenesis, as the plant growth regulators, the other components of culture media, the chronological age of explants, the developmental stage, and the surrounded environmental conditions (Tilkat and Onay, 2009 and Bar and Ori, 2014). It is well known that, plant growth regulators playing a critical role in the regulation of cell division tissue and organ differentiation Traas (2019). Research results on plant material from palm inflorescences showed that this type of tissue is very sensitive to growth regulators, especially auxins (Abahmane, 2013), also it was reported that, the plant hormone auxin presented as a central regulator of organ initiation (Bar and Ori, 2014). Moreover, with the other signaling pathways, in particular, cytokinin is an essential factor for the correct organ initiation (Bar and Ori, 2014; Traas, 2019 and Zhang et al., 2018). The induction of direct organogenesis from female inflorescence have been achieved by adjusting the ratio of cytokinin to the auxin (Abahmane, 2005; Abul-Soad 2012; Zayed 2017 and Khierallah et al., 2017), however (Zayed, 2011) succeeded in inducing the direct somatic embryogenesis from female inflorescence cultured on induction media rich of cytokinines only. Meanwhile, several studies demonstrated that, the source and size of explant affects the efficiency of regeneration (Plaza et al., 2015). The explant size found to be an important factor in the date palm female inflorescence somatic embryogenesis and plant regeneration in date palm Phoenix dactylifera (Sidkey and El-Dawayati, 2012), In addition the fine chopping of cultured explants of date palm shoot tip sections significantly improved the proliferation of somatic embryogenesis (Fki et al., 2003; Sane' et al., 2006 and Othmani et al., 2009). On the other hand, Benkirane et al. (2000) reported that the smallest explants sizes presented a higher morphogenetic capacity in the inflorescences fragments of Triticum durum.

On the light for the above introduction, the aim of present study is to develop an efficient protocol for date palm micropropagation by using inflorescences explant source, through investigating the effect plant growth regulators of different auxins type with constant concentration of cytokinins, accompanied with (the first time studying) the slicing method for the starting spikelet explant by (the fine chopping or the intact small segments) of female inflorescences explants of Barhe cultivar, on inducing the direct adventitious bud formation, to ensure identical plantlets production by tissue culture process for date palm inflorescences explant source.

\section{Materials and Methods}

The present study was conducted in the Central Lab. for Date Palm Researches and Development, Agricultural Research Center (ARC), Giza, Egypt.

\subsection{Plant material and explants preparation}

Immature female inflorescences of date palm (Phoenix dactylifera L.) cv. Barhe collected from adult female trees that grow under Egypt climate. spathes collected in early spring (February). Spathes are cream in color, soft, and $10-15 \mathrm{~cm}$ in length. Soap the collected spathes for $1 \mathrm{~h}$, and wash under running tap water. Disinfect the spathes by soaking in $40 \%$ of commercial Clorox $(5.25 \%$ sodium hypochlorite) while shaking for $20 \mathrm{~min}$. Rinse the spathes with sterilized distilled water three times and 
then the protective sheath was removed. Soak the sterilized spike explants in the antioxidant solution

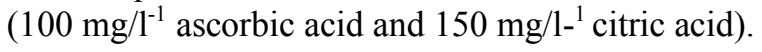

\section{Experiment design}

Two factors were studied to enhance the micropropagation protocol of date palm using immature female inflorescences explants: -

\section{1- The slicing methods for the inflorescence explant: -}

The sterilized female inflorescences spikes were sliced by two method

A- Spikes explants were cut into equal segments at 2-3 cm in length and contained 4-6 immature florets (the original slicing) (Fig 1a).

B- The same size of previous spikelet explant has completely chopped by sterile sharp scalpel, into small pieces (chopping slicing) (Fig. 1b).

All cultured explants have to be well contacted to the surface of the culture medium, as recommended by (Zayed, 2011).

\section{2- The induction culture medium}

The effect of different auxins types (2, 4-D, NAA, NOA) at different concentrations treatments $\left(0.5,1.0\right.$, and $\left.2.0 \mathrm{mg} / \mathrm{l}^{-1}\right)$ on the proliferation of inflorescences explants cultured on the induction culture medium.

The basic components of the induction culture medium are, the nutrient salts and vitamins of Murashige and Skoog (1962), $30 \mathrm{~g} / \mathrm{l}^{-1}$ sucrose, $200 \mathrm{mg} / \mathrm{l}^{-1}$ glutamine, $40 \mathrm{mg} / \mathrm{l}^{-1}$ adenine sulfate, and TDZ at 0.6 with BA at $1.0 \mathrm{mg} / \mathrm{l}^{-1}$ as described according to (Zayed, 2011). The $\mathrm{pH}$ was adjusted to. Media were dispensed $5.7 \pm 0.1$ before autoclaving into culture small jars $(150 \mathrm{ml})$ at the $35 \mathrm{ml} / \mathrm{jar}$ and were capped with polypropylene closures. The medium was then autoclaved for $20 \mathrm{~min}$ at $121^{\circ} \mathrm{C} 15 \mathrm{Ib} / \mathrm{in} 2$. Each treatment contained 3 replicates and each replicate contained one explant. Cultures were incubated in a temperature-controlled room at $27 \pm 2{ }^{\circ} \mathrm{C}$ under darkness and transferred to fresh media every 6 weeks' interval.

\section{Data were collected for different parameters during four subcultures as follows:}

1-The average value of adventitious bud formation/explant.

2-The average value of direct somatic embryo formation/explant.

3 -The average value of adventitious roots formation/explant.

4- The average degree value of browning /explant.

All data were evaluated by visual observation as degree Poor (1), Fair (2), Good (3), very good (4), and Excellent (5), as a followed recommendation by (El-Dawayati et al., 2018).

\section{Plant formation}

Transferred all differentiated direct adventitious shoots and somatic embryos obtained from all treatments to MS medium supplemented with $0.1 \mathrm{mg} / \mathrm{l}^{-1} \mathrm{NAA}$ and $0.05 \mathrm{BAmg} / \mathrm{l}^{-1}$ maintain cultures at $27 \pm 2{ }^{\circ} \mathrm{C}$ under a $16 \mathrm{~h}$ photoperiod of $40 \mu \mathrm{mol} / \mathrm{m} 2 / \mathrm{s}$ (cool-white fluorescent lamps) to resume their development.

\section{Plant acclimatization}

Plantlets hardened by culture on $1 / 2$ MS liquid medium supplemented with $10 \mathrm{~g} / \mathrm{l}^{-1}$ sucrose and $0.1 \mathrm{mg} / \mathrm{l}^{-1} \mathrm{NAA}$ (Zayed, 2011) Incubate cultures for 6 weeks at $27 \pm 2{ }^{\circ} \mathrm{C}$ under 16 -h photoperiod, and light intensity $80 \mu \mathrm{mol} / \mathrm{m} 2 / \mathrm{s}$ provided by (cool-white fluorescent lamps). Transfer plantlets in the greenhouse and soaked in $0.5 \%(\mathrm{w} / \mathrm{v})$ Benlate fungicide solution for 1-2 min. Put plantlets in plastic pots $5 \times 18 \mathrm{~cm}$ (torpedo) containing a mixture of peat moss, vermiculite, and sand $(1: 1: 1, \mathrm{v} / \mathrm{v} / \mathrm{v})$.

\section{Statistical analysis}

Data were expressed as mean \pm standard error (SE) and analyzed by ANOVA. To examine the significant differences among the treatments, (Duncan, 1955) multiple range test at $(\mathrm{P}<0.05)$, performed. 


\section{Results}

\subsection{Direct adventitious bud formation}

The present data reveal the effect of the addition of different types of auxins at different concentrations to the induction medium of MS salts supplemented with cytokinins of $0.6 \mathrm{mg} / \mathrm{l}^{-1} \mathrm{TDZ}$ and $1.0 \mathrm{mg} / \mathrm{l}^{-1} \mathrm{BA}$, and the slicing method for the cultured spikelet explants of the immature female inflorescence of date palm, to induce the direct adventitious bud differentiation). Direct somatic embryos, adventitious roots formation and browning phenomena were observed.

Data in Figure (2) illustrated that auxin type significantly effect on the formation of direct adventitious bud, where cultured spikelet explants of the immature female inflorescence on induction medium with cytokinins of $0.6 \mathrm{mg} / \mathrm{l}^{-1} \mathrm{TDZ}$ and $1.0 \mathrm{mg} / \mathrm{l}^{-1} \mathrm{BA}$ and NAA auxin gave the highest significant value of direct adventitious bud differentiation, followed significantly, by the value of direct adventitious bud differentiated from the spikelet explants on induction medium with 2, 4-D. On the other hand, spikelet explants cultured on induction medium with NOA completely failed to produce direct adventitious bud, also a necrosis appearance observed in the presence of NOA auxin.

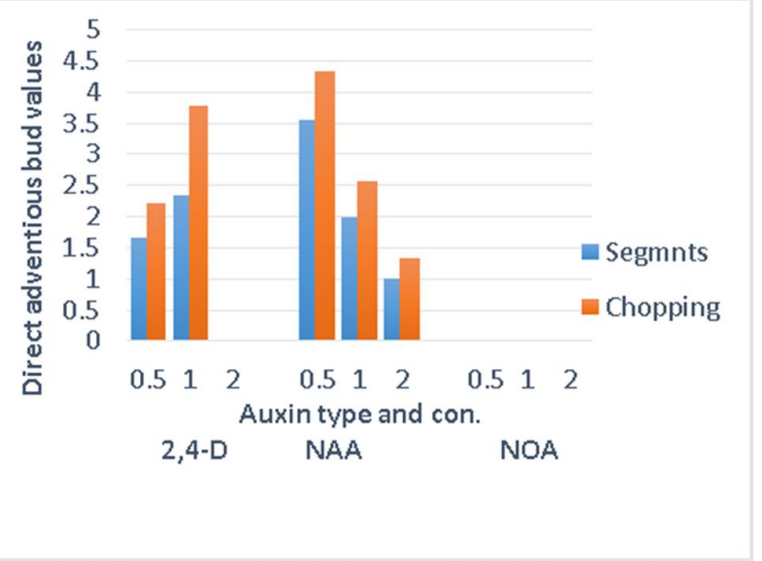

Fig. 2: Influence of auxin concentrations and slicing method on inducing direct adventitious bud from female inflorescences of date palm cv. Barhe.

The results also showed that, low level of auxin $\left(0.5 \mathrm{mg} / \mathrm{l}^{-1} 1\right)$ supplemented in the induction medium with cytokinins of $0.6 \mathrm{mg} / 1 \mathrm{TDZ}$ and $1.0 \mathrm{mg} / \mathrm{l}^{-1} \mathrm{BA}$ recorded the highest significant value of adventitious bud developed directly on the spikelet explants Fig. (3 a,b,c). But increasing the level of auxin to $(2.0 \mathrm{mg} / \mathrm{l})$ in the induction medium showed a dramatic reduction in the value of adventitious bud differentiation from cultured spikelet explants. Regarding the effect of the slicing methods of spikelet (Segments or fine Chopping), the present data revealed that fine Chopped spikelet gave the higher significant value of formation of direct adventitious bud than spikelet segments Fig. ( $3 \mathrm{~d}, \mathrm{e})$.

From data it can be indicated that differentiation of the direct adventitious bud from inflorescence explants affected significantly by the type of auxin, concentration, and the slicing method, as fine chopped spikelet cultured on induction media containing NAA at $0.5 \mathrm{mg} / 1$ recorded significantly the highest value of differentiated direct adventitious bud Fig.3a, whereas the cultured segments or fine chopped explants on induction media containing NOA, did not develop any direct adventitious bud from inflorescence explants, at all the studied concentrations.

\section{Direct somatic embryos}

Data in Fig. (4) indicated that the value of direct somatic embryos that developed from the initial meristems of the florets explants affected significantly by the type of auxin that added to the induction medium with cytokinins of $0.6 \mathrm{mg} / \mathrm{l}^{-1} \mathrm{TDZ}$ and $1.0 \mathrm{mg} / \mathrm{l}^{-1}$ BA. The cultured spikelet explants on induction medium containing NAA showed the highest value of direct somatic embryos formation, followed by, the value of direct somatic embryos formation of spikelet explants cultured on the induction medium containing 2,4-D. In contrast, the induction medium with cytokinins of $0.6 \mathrm{mg} / \mathrm{l}^{-1}$ $\mathrm{TDZ}$ and $1.0 \mathrm{mg} / \mathrm{l}^{-1} \mathrm{BA}$ supplemented with NOA gave the lowest value of direct somatic embryos formation of spikelet explants. 


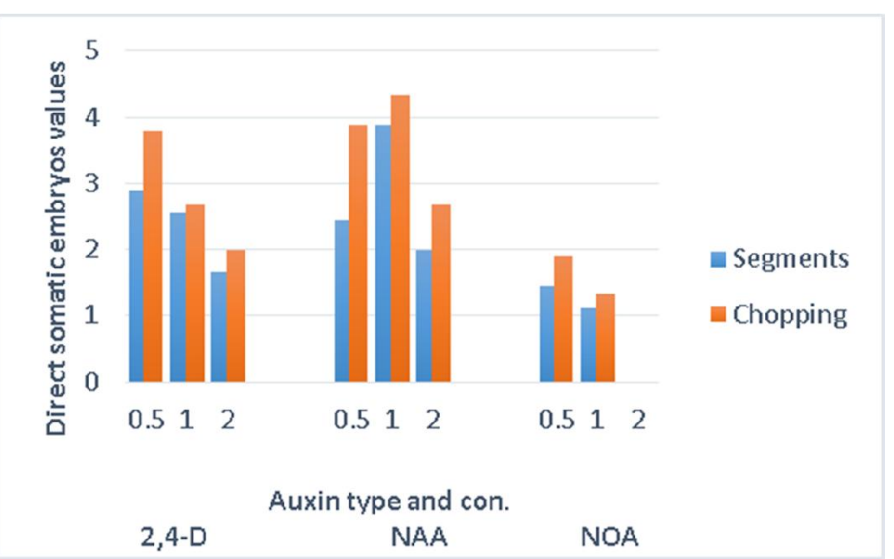

Fig. 4: Influence of auxin concentrations and slicing method on inducing direct somatic embryos from female inflorescences of date palm cv. Barhe.

The results showed that increasing the concentration of auxin in induction medium to $\left(2 \mathrm{mg} / \mathrm{l}^{-1}\right)$ recorded the lowest significant value of direct somatic embryos formation of cultured spikelet explants. On the other hand, the highest values of somatic embryos developed directly obtained from spikelet explants cultured on induction media containing auxin concentration at 0.5 and $1.0 \mathrm{mg} / \mathrm{l}^{-1}$ without significant difference in between. Regarding the slicing methods of the spikelet explants, it can be indicated from the results in Figure (2) that the slicing method for the spikelet explants highly affected the direct formation of somatic embryos, as the finely chopped spikelet explants had the highest significant value of direct somatic embryos frequency comparing to the segmented explants Fig. (5 a, b).

\section{Direct adventitious roots}

The results in Fig. (6), indicated that the highest proliferation of undesired formation of the abnormal direct adventitious roots from female inflorescences spikelet explants, observed clearly, with those spikelet explants, cultured on the induction medium, containing NOA. While, the spikelet explants, cultured on the induction medium, containing NAA, showed the lowest significant value of the formation of the direct adventitious roots.

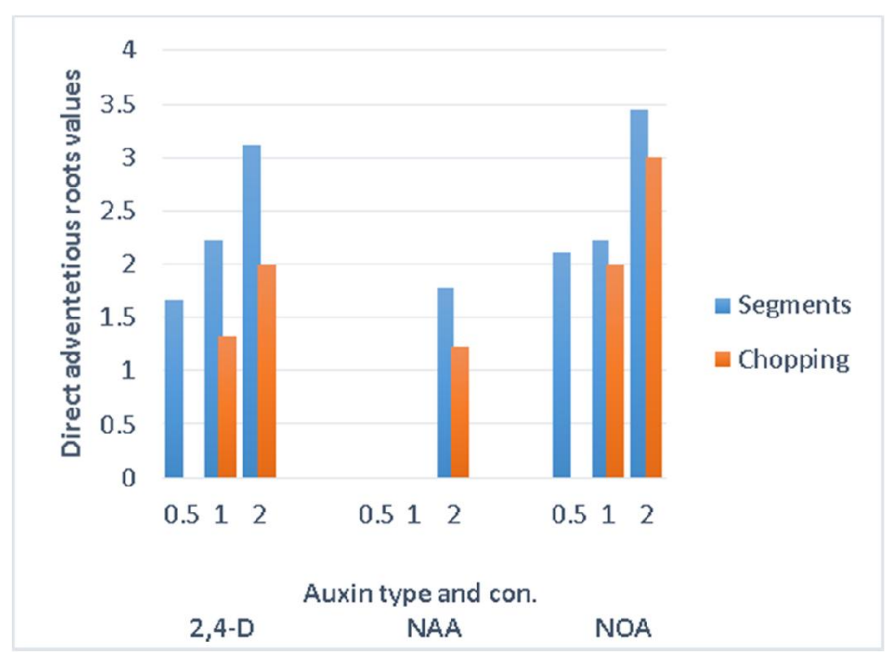

Fig. 6: Influence of auxin concentrations and slicing method on inducing direct adventitious roots from female inflorescences of date palm cv. Barhee.

Also, results showed that induction medium supplemented with a high concentration of auxin at $\left(2.0 \mathrm{mg} / \mathrm{l}^{-1}\right)$, produced the highest value of direct adventitious roots formation. Whereas explants cultured on the induction medium supplemented with auxin, at 1.0 and $0.5 \mathrm{mg} / \mathrm{l}^{-1}$, produced the lowest value of direct adventitious roots formation, without a significant difference in between. Also, finely 
chopped explants showed less value of adventitious roots formation than those explants, sliced as segments (Fig. 7a).

\section{Browning degree}

The observed browning degree on cultured spikelet explants in Fig. (8) highly increased when NOA implemented in the induction medium Methods of slicing spikelet explant were also significant.

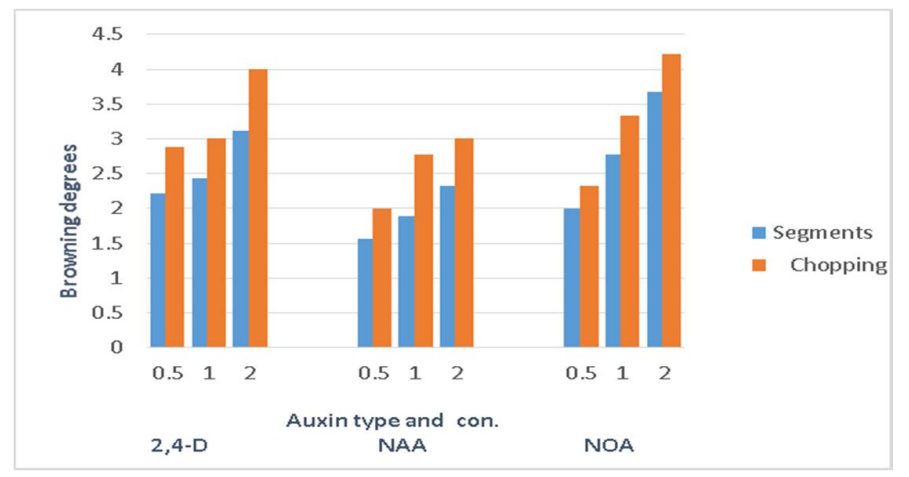

Fig. 8: Influence of auxin concentrations and slicing method on browning degree from female inflorescences of date palm cv. Barhee.

Also, spikelet explant presented the highest values of browning degree with increasing in the concentrations of auxins to $\left(2.0 \mathrm{mg} / \mathrm{l}^{-1}\right)$ whereas the lowest concentration of auxins at $\left(0.5 \mathrm{mg} / \mathrm{l}^{-1}\right)$ recorded the lowest significant degree of browning appearance. Data indicated that, fine chopping for cultured explants, highly increased the browning degree appearance Fig. (7b), comparing to those spikelet explants cultured on induction medium as sliced segments.

Table 1: Effect of slicing method on the accelerating of direct adventitious shoots and direct somatic embryos induction from cultured spikelet explants

\begin{tabular}{lcccc}
\hline \multirow{2}{*}{ Slicing methods } & \multicolumn{4}{c}{ Time period of morphogenesis response (week) } \\
\cline { 2 - 5 } & Direct shoot & Direct somatic & Direct root & Browning \\
\hline Segment explant & 24 & 18 & 8 & 4 \\
Chopping explants & 18 & 12 & 12 & 1 \\
\hline
\end{tabular}

In general, the initial visible observation for all cultured explants of all treatments appeared after 4-6 weeks as a slight enlargement Fig.9. accelerating of direct adventitious shoots and direct somatic embryos induction from cultured spikelet explants.

The direct adventitious bud formed mostly faster in fine chopping spikelet explants (18 weeks) comparing to the sliced segment spikelet explants ( 24 weeks). Also, the direct somatic embryos initiated by the chopping slicing method of spikelet explants after 12 weeks whereas initiated by segment slicing method of spikelet explants after 18 weeks without passing of callus phase for each. Browning phenomena observed within a week from chopped spikelet explants while observed after 4 weeks with segments spikelet explants.

Finally, all received plantlet via direct adventitious bud of date palm immature inflorescences, immediately transferred successfully to acclimatization stage with higher survival rate Fig. (10). Similarly, plantlets differentiated through direct somatic embryogenesis, also exhibited good growth and high survival rate.

\section{Discussion}

The immature female flowers histologically appear as a small mass of meristematic cells, subtending with small bracts (Zayed and Abdelbar, 2015), thus considered a successful source as regenerative explants of date palm micropropagation (Loutfi and Chlyah, 1998, Fayek et al., 2017). Zayed, (2011), reported that using the culture medium of the MS salts nutrient, supplemented with cytokinins $\left(0.6 \mathrm{mg} / \mathrm{l}^{-1} \mathrm{TDZ}+1.0 \mathrm{mg} / \mathrm{l}^{-1} \mathrm{BA}\right)$, effectively induced the direct somatic embryogenesis, from the immature female flowers spikelet. The present study showed that adding different types of auxins 
at different concentrations to the previous induction medium could also induce the direct adventitious bud formation from the cultured spikelet explants, which sliced as small segments $(2-3 \mathrm{~cm})$ or fine chopped into tiny sections. The obtained data revealed that spikelet explants cultured on medium containing low concentrations of NAA $\left(0.5 \mathrm{mg} / \mathrm{l}^{-1}\right)$ was the best to initiate direct organogenesis followed by $2,4-\mathrm{D}$ at $1 \mathrm{mg} / \mathrm{l}^{-1}$, the same result found with date palm inflorescences that developed adventitious bud by using NAA (Khierallah et al., 2017), also ,adventitious shoot regeneration achieved in leaves of wild pear ( $P$. communis var pyraster L.) by using the lowest NAA concentration $(1.0 \mu \mathrm{M})$, together with $8.8 \mu \mathrm{M}$ BA (Cabonil et al, 1999). Meanwhile, it was suggested that the proliferation of the young female inflorescences explants on a media characterized by a low auxin to cytokinin ratio, leading to bud formation either directly or after the multiplication of floral parts (Loutfi and Chlyah,1998; Wang et al., 2001 and Schaller et al., 2015). Moreover, the combination of one auxin and two cytokinins was found to be more effective on tissue growth and bud formation in date palm (Abahmane, 2005; Khierallah et al., 2017 and Mazri et al., 2017), also it was reported that the induction of embryogenesis and organogenesis were accomplished on media supplemented with auxin (2.4-dichloroacetic acid or a-naphthaleneacetic acid) alone or in combination with cytokinin (Trieu and Harrisson 1996 and Kouassi et al., 2017). On the other hand, the presented study showed that using NOA auxin at different concentrations failed to induce proliferation of direct adventitious bud from inflorescences explants, also, the lowest value of direct somatic embryos recorded, moreover, the explants turned in necrotic appearance. Similar result was found by Abahmane (2005) that using $\mathrm{mg} / \mathrm{l}^{-1}$ of NOA in culture media of date palm inflorescences explants resulted in $50 \%$ of culture necrosis during the first 3 months of culture.

Our result showed that the culture explants on high level of auxins, resulted in abnormal direct adventitious roots formation. Regarding the growth regulator balance on floral explants of date palm, it has been shown that high auxin/cytokinin ratios NOA $\left(0.5 \mathrm{mg} / \mathrm{l}^{-1}\right)$, IBA $\left(0.5 \mathrm{mg} / \mathrm{l}^{-1}\right), \mathrm{BA}\left(0.1 \mathrm{mg} / \mathrm{l}^{-1}\right)$ allow a high ratio of tissue reactions, but root formation was the most frequent (Abahmane, 2013). Ikeuchi et al., (2013) maintained that the balance between two plant hormones, auxin and cytokinin, determines the state of differentiation and dedifferentiation, since a high ratio of auxin-to-cytokinin induces root. Moreover, Canher et al., (2020) illustrated that, the wound-induced signal, highly modulated auxin content by affecting the subsequently expression of auxin biosynthesis and polar auxin transport genes, thereby stimulating adventitious roots induction.

In general, this type of differentiated adventitious roots, was not functional and by the time they turned in brown and completely dried, but it inhibits any subsequent normal differentiation from the meristematic cells.

Concerning to the browning phenomena appearance in the present study, it is well known that oxidation and phenolic accumulation followed by rapid explants browning has common in date palm tissue culture (Meziani et al., 2016). Meanwhile, Fayek et al., (2017) reported that the lowest value of browning was produced from cultured immature of Phoenix dactylefra infloresences explants on medium containing $1.0 \mathrm{mg} / \mathrm{l}^{-1} \mathrm{TDZ}$ and $0.5 \mathrm{mg} / \mathrm{l}^{-1} \mathrm{NAA}$, and in the leaf and inflorescence slices, of Areca catechu L. cultured on medium at high level of auxin, recorded the highest value of browning degree (Karun et al., 2004), which agreed with the obtained results in the presented study.

It was reported that, the source and size of explant affects the efficiency of regeneration (Plaza et al., 2015). In the present study, slicing method by fine chopping for the initial spikelet explants of immature date palm inflorescences, significantly influenced on their response to produce direct organogenesis during short period of proliferation, The same finding agreed with Othman et al., (2009) who noted that chopped explant segments at (5-10 mm long) of juvenile leaves of the date palm shoot tip, cultured on $5 \mathrm{mg} / \mathrm{l}^{-1} \quad 2,4-\mathrm{D}$, firstly resulted in direct embryogenesis without a callus phase presence. Also, in date palm, dividing small cells had an embryogenic appearance, with a protein-rich cytoplasm, small vacuoles, and a large nucleus (Sane et al., 2006 and AL-Mayahi 2015). Sane et al., (2012) chopped the granular calli of date palm to initiate embryogenic cell suspensions. This is could be explained by the higher morphogenetic capacity of the small explants fragments, as mentioned by Benkirane et al., (2000). Also, Gugsa et al., (2011) reported that the in vitro growth of small and intermediate-sized tef explants successfully started to initiate direct somatic embryos, at the edges of the scutellum, before callus formation. Whereas, the large explants, tended to form initial callus before appearing of the somatic embryos. It was suggested that explants with reduced size, showed the synthesis of new cell wall components, such as oligosaccharides, that can act as signals, to the cell to 
resume again the mitotic cycle (Tran Thanh Van and Bui, 2000). Moreover, the small explants, highly exposed to contact with the surface of the culture medium, and can be considered to be more stressed, which increasing the cell's metabolism (Feher et al., 2003).On the opposite side, Nair et al., (2018) found that in the male immature flower bud explants of banana, the optimum length at $(3 \mathrm{~cm})$, exhibited better survival, while smaller explants size, found to be not suitable for culture initiation, it was suggested that the larger explants possessing more nutrient reserves and endogenous plant hormones to sustain the culture El Boullani et al., (2017).
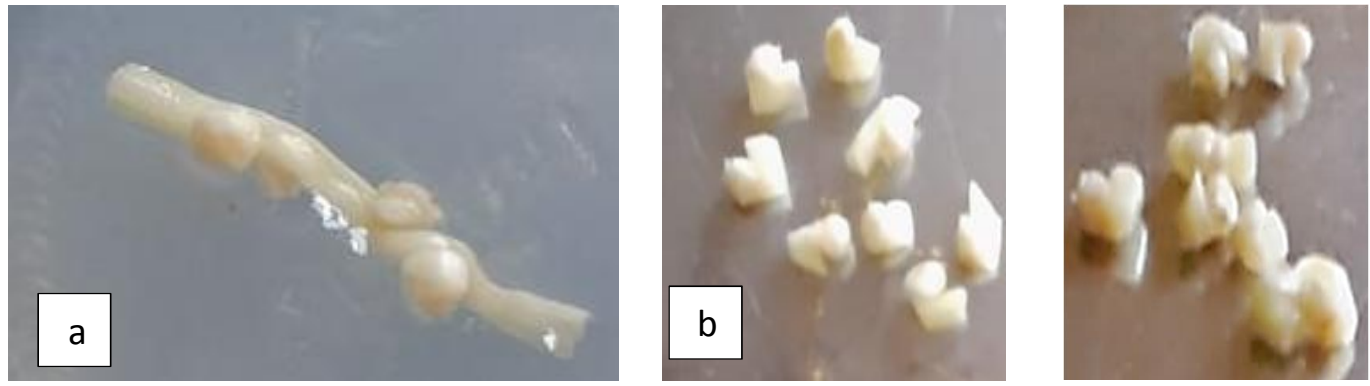

Fig. 1: Fine Chopped spikelet gave the higher significant value of formation of direct adventitious buds.
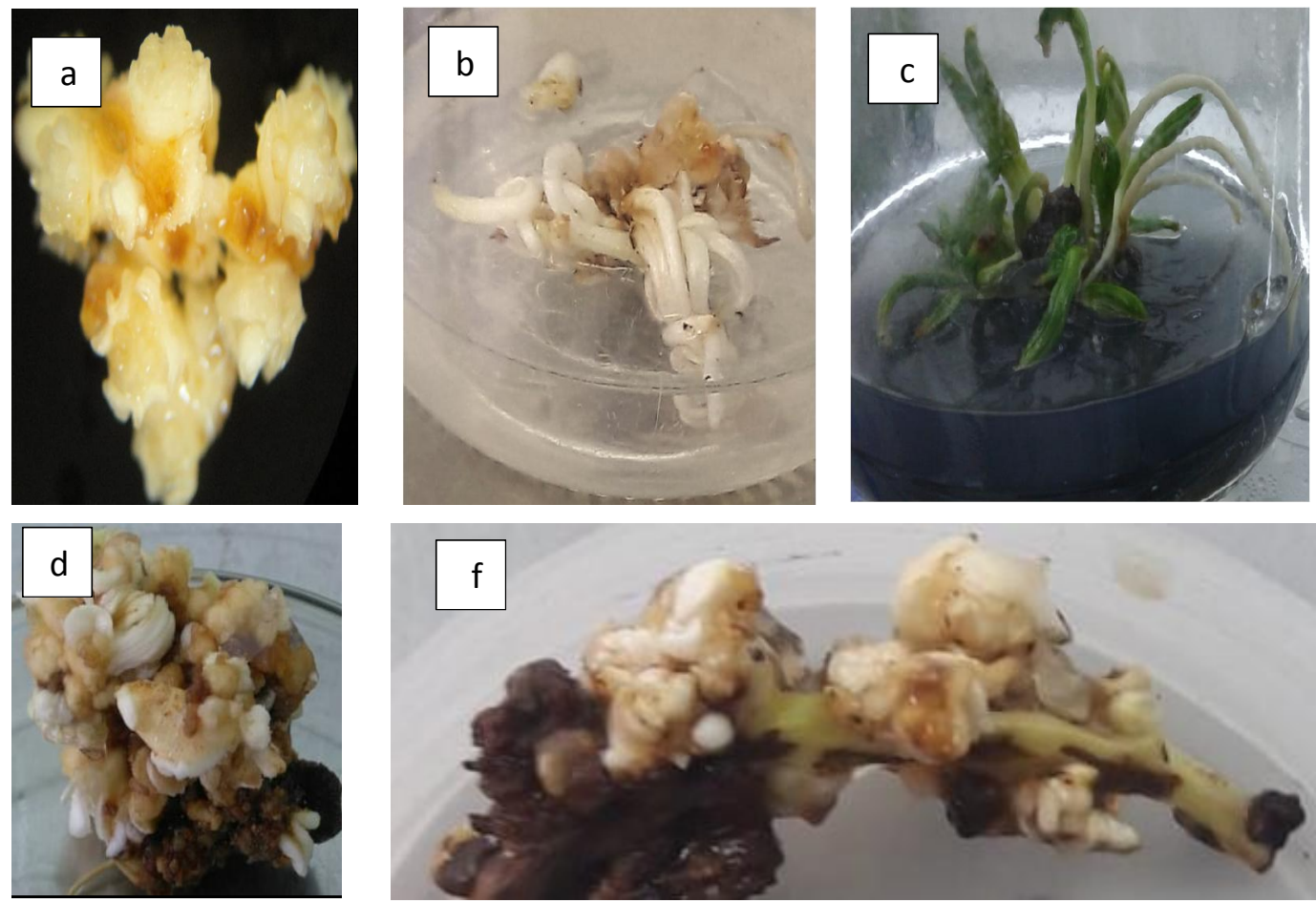

Fig. 3: Fine Chopped spikelet showed the higher ability for initial direct adventitious buds formation, especially cultured on induction medium, of. $5 \mathrm{mg} / 1 \mathrm{NAA}$ and cytokines (a). Differentiated and Developing direct adventitious shoots after 18 weeks from Chopped spikelet explants $(b, c)$. High frequency of direct adventitious shoots occurring by chopping (d) than the intact segments (f) of slicing method for the spikelet explants. 

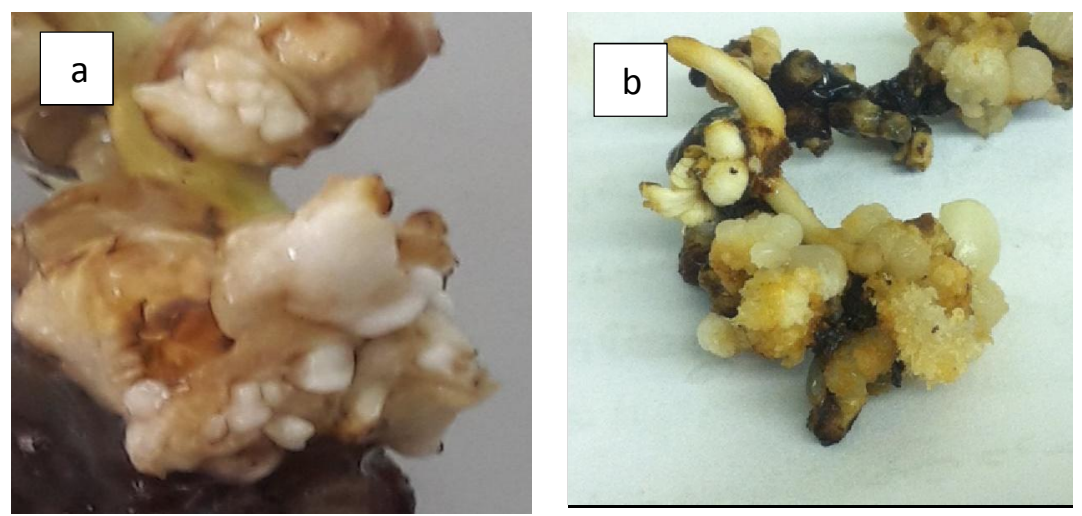

Fig. 5: High frequency of direct somatic embryogenesis occurring by chopping(a) than the intact segments (b) of slicing method for the spikelet explants.
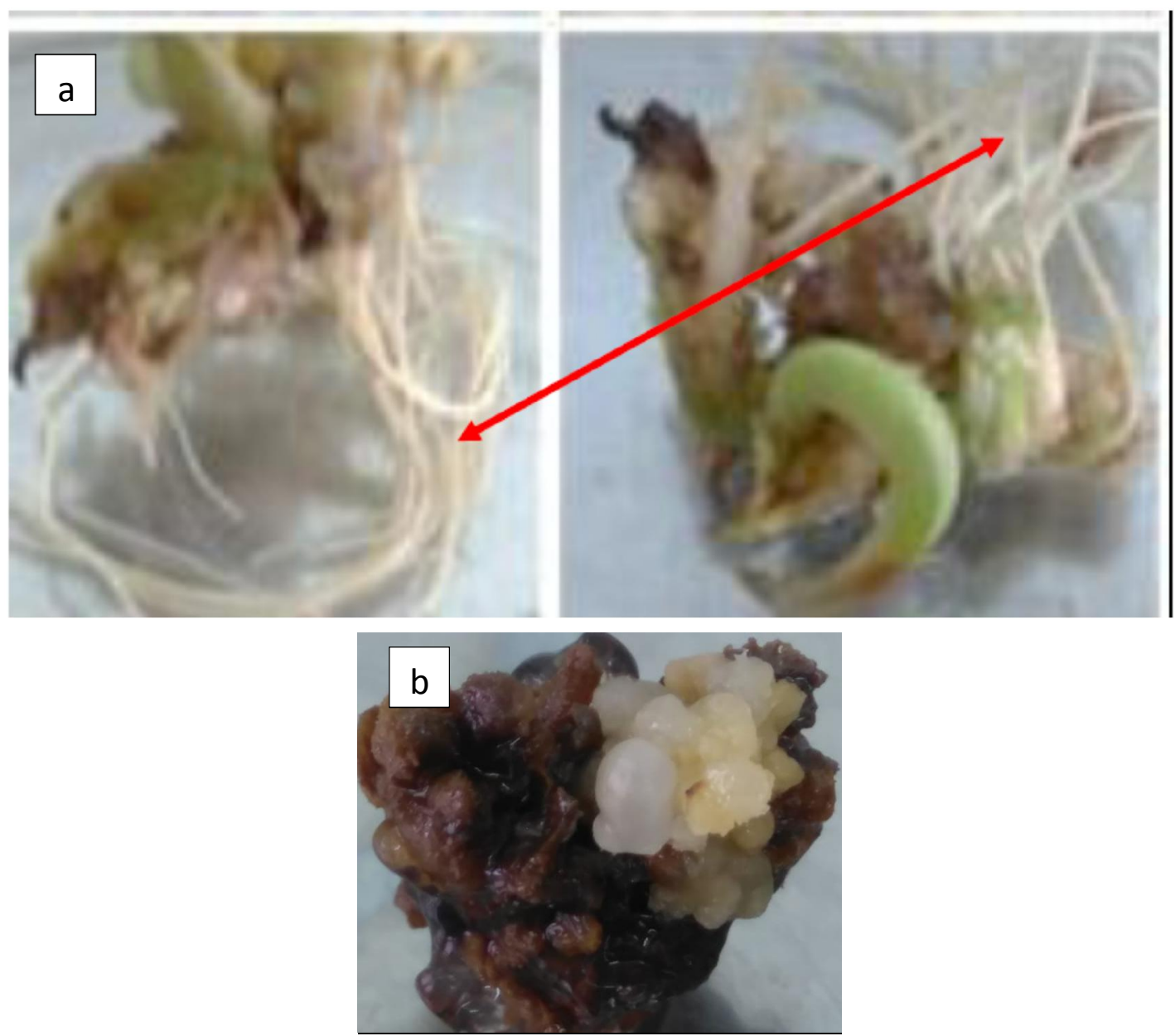

Fig. 7: Chopped explants showed less value of adventitious roots formation than those explants, sliced as segments(a), butfine chopping for cultured explants, the browning degree appearance highly increased in chopped cultured spikelet explants (b). 


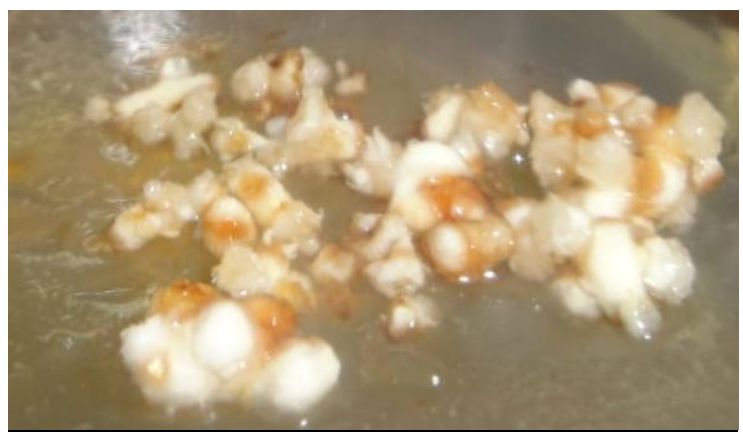

Fig. 9: Slight enlargement appeared after 4-6 weeks in chopped cultured spikelet explants in all treatments.
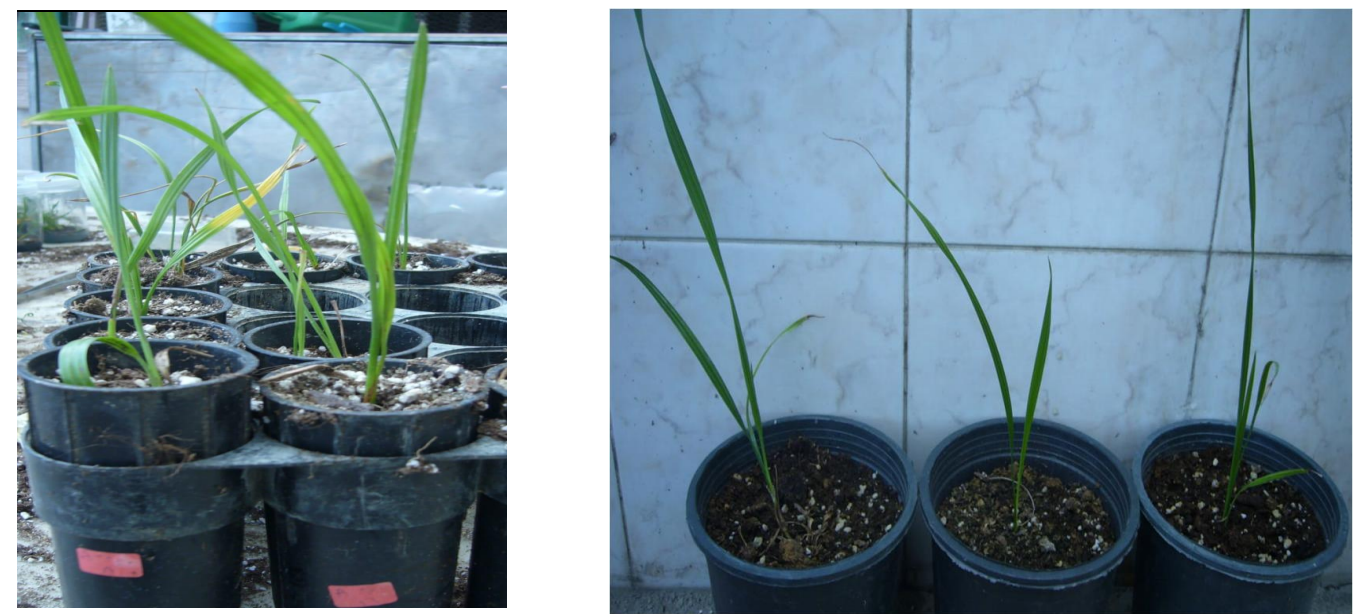

Fig. 10: Plantlet via direct adventitious bud of date palm immature inflorescences, immediately transferred successfully to acclimatization stage with higher survival rate.

\section{Conclusion}

This study demonstrated that, culturing immature inflorescences of date palm cv. Barhe on the induction medium of the appropriate ratio of the NAA auxin type at $0.5 \mathrm{mg}-1$, with two cytokinins of TDZ at $0.6 \mathrm{mg}-1$ and BA $1.0 \mathrm{mg} / \mathrm{l}^{-1}$, in addition to using the slicing method by fine chopping for the spikelet explants, showed the most satisfying results, to induce direct organogenesis by adventitious bud formation, where the hormonal balance and appropriate explants size, are important to induce the immature inflorescences proliferation in date palm. Developing the date palm micropropagation protocol by inflorescences explants considered a reliable and rapid opportunity to avoid the shortage of date palm offshoots and covering the commercial demands on the date palm plantlets.

\section{References}

Abahmane, L. 2005. Micropropagation par tissus inflorescentiels du palmier dattier (Phoenix dactylifera L.): Un outil efficace pour la sauvegarde des génotypes rares. Al-Awamia, 113:49-60.

Abahmane, L., 2013. Recent achievements in date palm (Phoenix dactylifera L.) micropropagation from inflorescence tissues. Emir. J. Food Agric., 25 (11): 863-874.

Abahmane, L., 2017. Cultivar-dependent direct organogenesis of date palm from shoot tip explants. In: Al-Khayri JM, Jain S, Johnson D (eds) Date palm biotechnology protocols, Vol I, Tissue culture applications. Springer, New York, pp 3-15.

Abul-Soad, A.A., 2012. Influence of inflorescence explant age and 2, 4-D incubation period on somatic embryogenesis of date palm. Emir. J. Food Agric., 24:434 
Ali, A.H. and E.M. Abdulzhara, 2018. Histological study of direct somatic embryogenesis in date palm cultured in vitro. Plant Archives, 18(2): 2199-2206.

Al-Khayri, J.M., 2011. Growth, proline accumulation and ion content in sodium chloride stressed callus of date palm. In Vitro Cellular \& Developmental Biology - Plant 38.

AL-Mayahi, A.M.W., 2015. An efficient protocol for indirect somatic embryogenesis and shoot organogenesis from leaf segments of date palm (Phoenix dactylifera L.) cv. Quntar. African Journal of Agricultural Research, 10 (10), 1031-1042.

Al-Mssallem, M.Q., R.M. Alqurashi, and J.M. Al-Khayri, 2019. Bioactive Compounds of Date Palm. Ref. Series Phytochem.

Amit, K., A.K. Gupta, R.M.K. Harish, M. Phulwaria, T. Agarwal, N.S. Shekhawat, 2014. In vitro propagation, encapsulation, and genetic fidelity analysis of Terminalia arjuna: a cardioprotective medicinal tree. Appl. Biochem. Biotechnol., 173:1481-1494.

Anitha Karun, E.A., E. Siril, Radha, and V.A. Parthasarath, 2004. Somatic embryogenesis and plantlet regeneration from leaf and inflorescence explants of arecanut (Areca catechu L.). Current Science, 86(12): 1623-1628.

Aslam, J., S.A. Khan, A.J. Cheruth, A. Mujib, M.P. Sharma, and P.S. Srivastava, 2011. Somatic embryogenesis, scanning electron microscopy, histology and biochemical analysis at different developing stages of embryogenesis in six date palm (Phoenix dactylifera L.) cultivars. Saudi Journal of Biological Sciences, 18(4): 369-380.

Asthana, P., V.S. Jaiswal and U. Jaiswal, 2011. Micropropagation of Sapindus trifoliatus L. and assessment of genetic fidelity of micropropagated plants using RAPD analysis. Acta Physiol Plant $33: 1821-1829$.

Bar, M., and N. Ori, 2014. Leaf development and morphogenesis. Development, 141(22), 4219-4230.

Bekheet, S., 2013. Direct organogenesis of date palm (Phoenix dactylifera L.) for propagation of trueto-type plants. Scientia Agriculturae, 4(3):85-92.

Benkirane, H.S, A. Abounji, H. Chlyah Chlyah, 2000. Somatic embryogenesis and plant regeneration from fragments of immature inflorescences and coleoptiles of durum wheat Plant Cell, Tissue and Organ Culture, 61:107-113.

Caboni, E., M.G. Tonelli, P. Lauri, S. D'Angeli, and C. Damiano, 1999. In vitro shoot regeneration from leaves of wild pear. Plant Cell, Tissue and Organ Culture, 59: 1-7.

Canher, B., J. Heyman, M. Savina, A. Devendran, T. Eekhout, I. Vercauteren, and L. De Veylder, 2020. Rocks in the auxin stream: Wound-induced auxin accumulation and ERF115 expression synergistically drive stem cell regeneration. Proceedings of the National Academy of Sciences, 117: $16667-16677$.

Chao, C.T., and R.R. Krueger, 2007. The date palm (Phoenix dactylifera L.): overview of biology, uses, and cultivation. Hort. Sci., 42:1077-1082.

Duncan, D.B., 1955. Multiple range and multiple F tests. Biometrics, 11: 1-42.

El Boullani, R., K. Lagram, A. El Mousadik, and M.A. Serghini 2018. Effect of explants density and size on the in vitro proliferation and growth of separated shoots of globe artichoke (Cynara cardunculus var. scolymus L.). Journal of Materials and Environmental Sciences 8 (7), pp. 24692473.

El-Dawayati, M.M., H.S. Ghazzawy, and M. Munir, 2018 Somatic embryogenesis enhancement of date palm cultivar Sewi using different types of polyamines and glutamine amino acid concentration under in-vitro solid and liquid media conditions. International Journal of Biosciences, 12(1):149159. http://dx.doi.org/10.12692/ijb/12.1.149-159.

El-Dawayati, M.M., S. El-Sharabasy, and S. Gantait, 2020. Light Intensity-Induced Morphogenetic Response and Enhanced $\beta$-Sitosterol Accumulation in Date Palm (Phoenix dactylifera L. cv. Hayani) Callus Culture. Sugar Tech., 22: 1122-1129.

El Hadrami, A., and J.M. Al-Khayri, 2012. Socioeconomic and traditional importance of date palm. Emirates Journal of food and Agriculture, 24(5):371.

Fayek, M.A., M. Helmy, E.M.M. Zayed, and M.R. Ahmed, 2017. Plant regeneration from immature female inflorescence explants of date palm (Phoenix dactylifera L.) via direct somatic embryogenesis. Bioscience Research, 14(4):895-899.

Feher, A., P. Taras, Pasternak and D. Dudits, 2003. Transition of somatic plant cells to an embryogenic state. Plant Cell Tissue and Organ Culture, 74(3):201-228. 
Fki, L., R. Masmoudi, N. Drira, and A. Rival, 2003. An optimised protocol for plant regeneration from embryogenic suspension 8256 Appl Microbiol Biotechnol (2018) 102:8229-8259 cultures of date palm, Phoenix dactylifera L. cv. Deglet Nour. Plant Cell Rep., 21:517-524.

Gantait, S., M.M. El-Dawayati, J. Panigrahi, C. Labrooy, and S.K. Verma, 2018. The retrospect and prospect of the applications of biotechnology in Phoenix dactylifera L. Applied microbiology and biotechnology, 102(19): 8229-8259.

Gugsa, L., and J. Kumlehn, 2011. Somatic embryogenesis and massive shoot regeneration from immature embryo explants of Tef. Biotechnology Research International. https://doi.org/10.4061/2011/309731.

Ikeuchi, M., K. Sugimoto, and A. Iwase, 2013. Plant callus: mechanisms of induction and repression. The Plant Cell, 25(9): 3159-3173.

Jain, S.M., 2012. Date palm biotechnology: current status and prospective—an overview. Emir J.

Johnson, D.V., 2011. Introduction: date palm biotechnology from theory to practice. In: Jain SM, AlKhayri JM, Johnson D (eds) Date palm biotechnology. Springer, Dordrecht, 1-11

Kazeroonian, R., A. Mousavi, S.K. Jari, and M. Tohidfar, 2018. Factors Influencing in vitro Organogenesis of Chrysanthemum morifolium cv.'Resomee Splendid'. Iranian journal of Biotechnology, 16(2).

Khierallah, H.S.M., S.M. Bader, and M.A. Al-Khafaji, 2017. NAA-induced direct organogenesis from female immature inflorescence explants of date palm. In: Al-Khayri J, Jain S, Johnson D (eds) Date palm biotechnology protocols, Vol I. Methods in molecular biology, vol 1637. Humana Press, New York, 16-25

Kouassi, M.K., J. Kahia, C.N.G. Kouame, M.G. Tahi, and E.K. Koffi, 2017. Comparing the effect of plant growth regulators on callus and somatic embryogenesis induction in four elite Theobroma cacao L. genotypes. HortScience, 52(1): 142-145.

Kriaâ, W., B. Sghaier-Hammami, F. Masmoudi-Allouche, R. Benjemaa Masmoudi, and N. Drira, 2012. The date palm (Phoenix dactylifera L.) micropropagation using completely mature female flowers. C.R. Biol., 335:194-204.

Mazri, M. A., I. Belkoura, R. Meziani, B. Mokhless, and S. Nour, 2017. Somatic embryogenesis from bud and leaf explants of date palm (Phoenix dactylifera L.) cv. Najda. 3 Biotech, 7(1): 58. https://doi.org/10.1007/s13205-017-0676-y

Mazri, M.A., R. Meziani, I. Belkoura, B. Mokhless, and S. Nour, 2018. A combined pathway of organogenesis and somatic embryogenesis for an efficient large-scale propagation in date palm (Phoenix dactylifera L.) cv. Mejhoul. 3Biotech, 8: 215.

Meziani, R., F. Jaiti, M.A. Mazri, A. Hassani, S.B. Salem, M. Anjarne, M.A. Chitt, and C. Alem, 2016. Organogenesis of Phoenix dactylifera L. cv. Mejhoul: Influences of natural and synthetic compounds on tissue browning, and analysis of protein concentrations and peroxidase activity in explants. Scientia horticulturae, 204:145.

Murashige, T. and F. Skoog, 1962. A revised medium for rapid growth and bioassays with tobacco tissue cultures. Physiologica Plantarum, 15: 473-497.

Nair, A.R.G., P. Ravichandran, and M. Bejoy, 2018. Direct shoot regeneration from male immature flower bud of Musa paradisiaca Linn. cv. Poovan (AAB). Plant Science Today, 5(4): 142-148

Othmani, A., C. Bayoudh, N. Drira, M. Marrakchi, and M. Trifi, 2009. Somatic embryogenesis and plant regeneration in date palm Phoenix dactylifera L., cv. Boufeggous is significantly improved by fine chopping and partial desiccation of embryogenic callus. Plant Cell Tissue Organ Culture, 97:71-79.

Plaza, S., R. Blösch, and Z. Tadele, 2015. Efficiency of in vitro regeneration is dependent on the genotype and size of explant in tef [Eragrostis tef (Zucc.) Trotter]. Advances in Crop Science and Technology, 3(3):1000179.

Rehab, A. Sidky and M.M. Eldawyati, 2012. Proliferation of Female Inflorescences explants of Date Palm. Annals of Agricultural Sciences, 57(2):161-165

Sane, D., F. Aberlenc-Bertossia, Y.K. Gassama-Diai, M. Sagna, M.F. Trouslot, Y. Duveal, and A. Borgel, 2006. Histocytological analysis of callogenesis and somatic embryogenesis from cell suspensions of date palm (Phoenix dactylifera). Ann. Bot. 98:301-308 
Sané, D., F. Aberlenc-Bertossi, L.I.D. Diatta, B. Guèye, A. Daher, M. Sagna, Y. Duval, and A. Borgel, 2012. Influence of growth regulators on callogenesis and somatic embryo development in date palm (Phoenix dactylifera L.) Sahelian cultivars. The Scientific World Journal. https://doi.org/10.1100/2012/837395.

Schaller, G.E., A. Bishopp, and J.J. Kieber, 2015. The yin-yang of hormones: cytokinin and auxin interactions in plant development. The Plant Cell, 27(1): 44-63.

Tilkat, E., and A. Onay, 2009. Direct shoot organogenesis from in vitro derived mature leaf explants of pistachio. In vitro Cellular and Developmental Biology - Plant45, 92-98, doi:10.1007/s11627008-9168-4.

Traas, J., 2019. Organogenesis at the shoot apical meristem. Plants, 8(1): 6.

Tran, T., K. Van, and B. Van Le, 2000. Current status of thin cell layer method for the induction of organogenesis or somatic embryogenesis, In: Somatic embryogenesis in woody plants, Vol 6, S.J. Mohan, P.K Gupta and RJ. Newton (eds), Kluwer Academic Publishers, Dordrecht, 5192.

Trieu, A.T., and M.J. Harrisson, 1996. Rapid transformation Medicago truncatula via shoot organogenesis. Plant Cell Rep., 16: 6-11

Wang, S., L. Tang, and F. Chen, 2001. In vitro flowering of bitter melon. Plant cell reports, 20(5), pp.393-397. Journal of Genetic Engineering and Biotechnology, 14(2): 363-370.

Zayed, E.M.M. and O.H. Abdelbar, 2015. Morphogenesis of immature femal inflorescences of date palm in vitro. Annals of Agricultural Science, 0570-1783.

Zayed, E.M.M. and O.H. Abdelbar, 2017. Histological Evidence of Indirect Somatic Embryogenesis from Immature Female Date Palm Inflorescences. In Date Palm Biotechnology Protocols Volume I (pp. 129-144). Humana Press, New York, NY. https://doi.org/ 10.1007/978-1-49397159-5.

Zayed, E.M.M., 2011. Propagation of Phoenix dactylifera L. Chamaerops humilis L. and Hyophorbe verschaffeltii L. palms by using tissue culture technique. Ph.D. Thesis, Department of Horticulture, Faculty of Agriculture, Cairo University, Egypt, 130- 136.

Zayed, E.M.M., 2017. Direct Organogenesis and Indirect Somatic Embryogenesis by In Vitro Reversion of Mature Female Floral Bud to a Vegetative State. In Date Palm Biotechnology Protocols Volume I (pp. 47-59). Humana Press, New York, NY. https://doi.org/ 10.1007/978-14939-7159-5.

Zayed, E.M.M., O.H. Abdelbar, A.F.M. Zein El- Din, H.H. Manaf, 2016. Floral reversion of mature female inflorescences of date palm in vitro. Annals of Agricultural Science, 61(1): 125-133.

Zayed, Z.E., 2017. Enhanced indirect somatic embryogenesis from shoot-tip explants of date palm by gradual reductions of 2, 4-D concentration. In Date Palm Biotechnology Protocols, 1: 77-88. Humana Press, New York, NY. https://doi.org/ 10.1007/978-1-4939-7159-6.

Zhang Y, Wang B, Guo L, Xu W, Wang Z, Li B, Zhang J 2018. Factors influencing direct shoot regeneration from leaves, petioles, and plantlet roots of triploid hybrid Populus sect. Tacamahaca. J For Res 29:1533-1545. 